\title{
A COMPARATIVE INVESTIGATION INTO THE REPRESENTATION OF RUSSIA IN APARTHEID AND POST-APARTHEID ERA SOUTH AFRICAN HISTORY TEXTBOOKS
}

\author{
DOI: http://dx.doi.org/10.17159/2223-0386/2018/n18a4
}

Tarryn Halsall

Social Science Education Cluster

University of KwaZulu-Natal

Tc.halsall@gmail.com
Johan Wassermann

Social Science Education Cluster

University of KwaZulu-Natal

Johanwassermann@gmail.com

\section{Abstract}

In this comparative study we employed a quantitative approach, underpinned by the interpretivist paradigm, to analyse the content on Russia as found in Apartheid and post-Apartheid History textbooks. This was done by means of qualitative content analysis. The focus of the analysis was exclusively on the historical content or substantive knowledge as it related to Russia. What emerged was that the political eras Russia was studied under remained remarkably similar across the Apartheid and post-Apartheid eras. However, clear discernible similarities and differences were otherwise detectable. While big men dominated the content of both eras the approach adopted by the post-Apartheid era History textbooks towards them were generally more critical. While a fear of Communism was imbedded in the Apartheid era History textbooks, the opposite can be said of the post-Apartheid era textbooks. What this points to is that during both political eras the content on Russia was adapted to suit the prevailing identity politics, national narratives and ideology of the time - closed and insular under Apartheid and open and critical in the post-Apartheid era.

Keywords: Russia; South Africa; History textbooks; Apartheid; PostApartheid; Ideology.

\section{Introduction}

The traditional beginning of Russian ${ }^{1}$ History is regarded as being 862, with the formation of a loose federation amongst East Slavic tribes. This federation spawned an Orthodox Slavic culture which in time embraced Tsardom. Expansion under the Tsars created a vast Russian Empire stretching from Eastern Europe to the Pacific Ocean. Tsardom and its feudal nature were eventually overthrown during the Russian Revolution of 1917. The Russian Revolution ushered in an era of Communist rule under the Union of Soviet

1 Throughout the article the term Russia will be used to refer to Tsarist, Communist and post-Communist Russia. 
Socialist Republics (USSR). Communist rule in Russia ended in 1992, when the USSR was replaced by the Russian Federation which embraced Capitalism and aspects of Western democracy.

South Africa has a long relationship with Russia which has been determined by three significant ideological eras: Colonialism, Apartheid and post-Apartheid. Especially during the latter two ideological eras significant connections developed between the two countries. Soon after the rise of Communism in Russia the South African Communist Party (SACP) was established in 1921. This served to strengthen ties between Russia and South Africa. This relationship was deepened when the African National Congress (ANC) formed an alliance with the SACP to oppose the racist Apartheid policies of the ruling National Party (NP). Despite Communism being banned by the NP in 1950, Russia continued to aid the SACP. This was done as part of a broader ideological struggle tied to the Cold War, which on the one side had the Western aligned NP overseeing white minority rule portraying Russia and Communist and it's in its opposition to Apartheid and Capitalism as the Rooi Gevaar (Red Peril), and on the other the liberation movements experiencing Russia and Communism as the antidote to racial oppression. In the end the demise of Communist Russia in 1992 also ushered in the fall of the NP and apartheid. This paved the way for the 1994 democratic elections in South African which brought the ANC and its ally the SACP to power. In time the new South Africa and Russia, both products of significant political shifts, formed with China, India and Brazil, an economic alliance called BRICS. This served to entrench relations between South Africa and Russia in a new way.

With reference to History Education Russia has been studied in the senior grades of schooling during both the Apartheid and post-Apartheid eras. This is significant in that the challenges posed by what Russia stood for to the NP's reign could have affected the way it was represented in the historical content within the Apartheid era History textbooks. Similarly, the support offered by Russia to the liberation movements opposing Apartheid, and the contemporary relationships within BRICS could again have affected the representation of Russia in in the historical content within the post-Apartheid era History textbooks.

Using the aforementioned background and context as a framework this article investigated the representation of Russia in South African History textbooks across, ideologically-speaking, two very different political eras. More specifically the focus fell on the historical content, or substantive knowledge, 
as contained in the History textbooks (the programmatic curriculum) of the two eras. Differently put, the focus of the analysis fell on the written text. In the process visual images, paratext (textboxes), activities and exercises and historical sources were not engaged with. Although this meant a narrow focus we deemed, in terms of a comparative investigation, this a researchable undertaking. Outside of historical content it would have been extremely challenging to do a comparative study on how Russia was represented in the Apartheid and post-Apartheid era History textbooks. This is because the nature of History at school has changed radically from the Apartheid to the post-Apartheid era. During the former History at school level was mostly a memory discipline underpinned by passive forms of rote learning, and an Afrikaner Nationalist historiography that foregrounded white achievements. In line with the changes experienced by post-Apartheid society History at school has also transformed fundamentally. It is now a disciplinary discipline with active forms of learning that spoke to the constitutional democracy based on human rights that it serves (Wassermann, 2018). These changes are clearly visible when simply paging through the History textbooks of the two eras. However, such paging reveals very little about historical content. Therefore, room for this study exist since little to no research has been conducted on how the intricate relationships between South Africa and Russian over the past hundred-years affected the representation of the latter within the content of Apartheid and post-Apartheid era History textbooks.

\section{Literature review}

It has been argued that the nature of History Education is to be found in the selection of national narratives. Many a time specific national narratives, based on the promotion of a selective memory, are promoted (Foster, 2011; Zajda \& Zajda, 2003). Selected narratives are used and manipulated in order to link a desired ideology to a society so as to instil a common set of values and identities (Engelbrecht, 2006; Foster, 2011). Pratte (1977) and Zajda and Zajda (2003) further detail that selected historical narratives are part of a power play to assert ideological dominance within History with the aim of establishing a tangible identity for the dominant group.

A national narrative can be equated to a preferred national identity. The envisaged national identity is created by manipulating historical knowledge according to presentist cultural or societal needs and norms (Foster \& Crawford, 2006; Porat, 2004). Foster and Crawford (2006) suggest that 
nations select a desired past and a desired national identity that best represents the nation. The chosen national identity often manifests itself in a refashioned historical memory gleaned from desired historical conceptions (Porat, 2004; Stojanovic, 2001; Zajda, 2007). This thinking is furthered by Porat (2004), Stojanovic (2001) and Zajda (2007) who argues that the appropriation of desired historical concepts can redefine a national identity. However, this can often offer a tainted view of History as it supports and promotes a dominant culture which suppresses views not regarded as favourable (Apple, 2004).

The process of selecting agreed upon national narrative can be built upon the use of selected ideas to promote a distinct national consciousness (Zajda, 2007). According to Foster (2011), the purpose of selecting favoured ideas is to promote a collective memory which reinforces an entrenched national consciousness. The purpose of this would be to solidify political and societal norms so as to create a particular interpretation of History that is more desirable for the nation (Pingel, 2010). History textbooks are ideally suited to act as constructors and disseminators of national narratives and identities (Apple \& Christian-Smith, 1991; Paxton, 1999; Wang, 2009).

Research on South African History textbook is a thriving field (Bertram \& Wassermann, 2015). This research covers a plethora of topics including, a focus on how Apartheid era textbooks were used to promote Afrikaner masters symbols and racism (du Preez, 1983; da Cruz, 2005), and the ideological differences between textbooks of the Apartheid and post-Apartheid eras (Engelbrecht, 2006). Amongst this research is also to be found a study comparing specialised and everyday subject knowledge between Apartheid and post-Apartheid era History textbooks (Bertram \& Bharath, 2011). In their study Bertram and Bharath found that contemporary Grade 6 History textbooks contained reduced substantive history knowledge when compared to the equivalent Standard 4 books of the 1980s dealing with the same topics. Additionally, the contemporary textbooks contained a more inclusive history and everyday knowledge and generic skills. In terms of History textbooks comparative studies with a South African focus are few and far between (Nishino, 2006; Chisholm, 2015). These comparative studies, furthermore, did not engage with the representation of the History of a specific country.

Internationally the available literature pertaining to the representation of Russia in History textbooks, other than Russian History textbooks itself, are also limited and contain no comparative studies. The literature that does exist is generally dated and promotes a common description of Russia as backward and ruled by 
tyrannical rulers (Anderson, 1954; Burkhardt, 1947-1948; Paddock, 1998).

The literature reviewed, as outlined above, clearly leaves room for an article such as ours which focusses on the comparative representation of Russia in South African History textbooks of the Apartheid and post-Apartheid eras. Additionally, the importance of a comparative study such as ours is argued for by Cavalli (2016) who states that it enables researchers to deduce the similarities or the differences found in textbooks so as to come to a greater understanding of the History that is being taught.

\section{Research design and methodology}

Research design and methodology are interlinked, with the former providing the planned structure, and the latter the means of data collection and analysis. For this article we employed an interpretivist paradigm. Interpretivists seek to understand truths constructed within a version of social reality. In this article this relates to the contrasting social realities of the ideological eras of Apartheid and post-Apartheid. The stark contrast between the two eras would therefore impact on the interpretation of Russia within these eras (Zhao, 2001). Since we employed an interpretivist paradigm we, to underscore our paradigmatic position, chose to use a qualitative approach. The rationale for using a qualitative approach is aligned to our research focus on the social construction of Russia during two very different ideological eras. In the light of this the need for our research approach to be qualitative in nature is imperative as it focusses on reality being a social construction (Bauer, Gaskell, \& Allum, 2000; Denzin \& Lincoln, 2008; Kahlke, 2014).

In order to gain a rounded understanding of the representation of Russia in Apartheid and post-Apartheid era textbooks a large enough sample was needed. For our research we chose to incorporate both convenience and purposive sampling. Cohen and Manion (1994) and Teddlie and Yu (2007) stipulate that convenience sampling is used to allow the researcher to select the most readily available and therefore the most convenient textbooks. From the outset we ensured that the textbooks selected were appropriate to the History curricula they were based on. For the Apartheid era textbooks we chose to employ mostly convenience sampling as it proved a challenge to find textbooks from this era. This was due to many schools no longer keeping them as they were outdated and for a different curriculum and political dispensation. Consequently, we were left with only a few textbooks from which to choose. We did, however, incorporate purposive sampling into the small selection of Apartheid era textbooks that 
we did acquire. This was done because we only needed three textbooks. As a result we specifically chose textbooks that, for the most part, shared a common publisher with the sampled post-Apartheid era textbooks.

We chose to label the three selected books, for analysis and ethical reasons, as Book A1, A2 and A3:

- Book A1: South Africa in the modern world (1910-1970), 1974, publisher: Shuter and Shooter, Standard 10 [Grade 12]: Chapter 3 (pp. 40-62) is the unit under analysis. Chapter 3 is entitled: The growth of totalitarian powers: Communist Russia to 1939.

- Book A2: Timelines, 1988, publisher: Maskew Miller Longman, Standard 10 [Grade 12]: Chapter 1: The rise of Soviet Russia which falls under the heading: The rise of the super-powers, 1917 to 1939 (pp. 1-24).

- Book A3: History for today, 1989, publisher: Juta Standard 10 [Grade 12]: Part One: General History is the section under study.

In terms of the selected Apartheid-era textbooks it is necessary to understand them contextually. The three chosen textbooks were published during three different phases of Apartheid: Book A1 was published in 1974, during the height of Apartheid. Book A2 was published in 1987, and although petty Apartheid was pretty much over, South Africa was still, despite global and internal resistance, an Apartheid state. Finally, Book A3 was published in 1989, when Apartheid, the Cold War and the Soviet Russia were winding down.

For the post-Apartheid textbooks, we only used purposive sampling as Cohen and Manion (1994) and Teddlie and Yu (2007) suggest that this type of sampling allows a cherry picking of textbooks for a specific purpose. Since we chose to use current in-circulation Curriculum in Assessment Policy (CAPS) History compliant History textbooks for our post-Apartheid textbook selection, there were numerous textbooks available to us. However, based on a need for as much continuity as possible we selected post-Apartheid era textbooks based on having, for the most part, the same publishers as the Apartheid era textbooks.

We have chosen to label the three selected textbooks, for analysis and ethical reasons, as Book B1, B2 and B3:

- Book B1: Top class, History, 2012, publisher: Shuter \& Shooter, Grade 11 [Standard 9]: The textbook is divided into terms and the term being analysed was Term 1: Communism in Russia 1900-1940 with the sub-heading: How was communism applied in Russia under Lenin and Stalin? (pp. 1-51). 
- Book B2: Focus, History, 2012, publisher: Maskew Miller Longman, Grade 11 [Standard 9]: The textbook is divided into terms. The term analysed was Term 1. The unit being analysed was Unit 1: Communist Russia, 1900 to 1940 (pp. 12-90).

- Book B3: Viva History, 2012, publisher: Vivlia, Grade 11 [Standard 9]: The textbook is divided into terms and the term being analysed was Term 1: Communism in Russia, 1900-1940 (pp. 3-56).

As part of our research methodology we chose to use qualitative content analysis, a subsection of content analysis. This allowed for the use of an open-coding system of analysis. Qualitative content analysis allows for the identification of patterns by means of codes thus allowing for an interpretation based on the emerged patterns (Elo \& Knygäs, 2008; Hsieh \& Shannon, 2005). It must, however, be borne in mind that qualitative content analysis permits a subjective interpretation of the patterns based on the contextual nature of the text. This is in contrast to content analysis which tends to allow for a more objective interpretation (Denzin \& Lincoln, 2008). Following the structure of qualitative content analysis our data analysis process was broken down into three distinct phases: preparation, organising and reporting.

In the preparation phase we divided the historical content on Russian History into the three main historical eras as found in the selected History textbooks. The three eras were: Tsarist Russia, Bolshevik Russia and Communist Russia. During the organising phase that followed categories were created through the use of open-coding. Finally, during the reporting phase, our created categories, and the patterns that emerged, were interpreted.

Using a comparative methodological approach, we have analysed the content related to the representation of Russia in the six textbooks from two different ideological eras. This was done by using the interpretivist paradigm and a qualitative approach to underpin the qualitative content analysis employed. The findings that emerged form the analysis process as outlined will be discussed next.

\section{Analysis - Findings on the representation of Russia in the content of Apartheid era History textbooks}

We have chosen to organise our analysis broadly along the historical eras as found in the sampled History textbooks: Russia under the Tsarist Regime, Russia during the Bolshevik Revolution, Russia under Lenin and Russia under Stalin. 
The main overall finding that was that Books A1 (1974) and A2 (1987) offered, throughout, a strong anti-Tsarist, anti-Communist and pro-West discourse. In contrast Book A3 (1989) offered a less critical approach to Communism, albeit still presenting an anti-Tsarist and pro-West positioning. The suggestion for the change in approach by Book A3 (1989) is that South Africa was nearing the end of Apartheid. At the same time the Cold War and Communist Russia, and by extension the "Red Scare", was winding down. Consequently there was, ideologically speaking, no longer any real need to maintain the same ideological position as in the past. In contrast, Books A1 (1974) and A2 (1987) both needed to adopt a critical approach towards Communism in keeping with the political sentiments as espoused by the National Party at the time.

Another finding that permeated all the historical eras in all three Apartheid era textbooks was the focus on big men. Whilst there was some difference in the representation of the various big male characters in terms of the amount of space allocated to each, Tsar Nicholas II, Vladimir Lenin, Leon Trotsky and Joseph Stalin, dominate the historical content. According to the three Apartheid-era textbooks these four men were instrumental in shaping Russian History. Consequently, other historical characters were under-represented or simply omitted.

Lenin and Stalin were across the analysed Apartheid-era History textbooks represented as being the masterminds behind Communist Russia. All three textbooks tended to perpetuate a similar image of Lenin - a good leader that can be admired. In contrast, Books A1 (1974) and A2 (1987) strongly associated Stalin with violence, brutality and absolute oppression. The representation of Stalin softened in the Book A3 (1989), perhaps in keeping with the changing circumstances in Soviet Russia. Where the three textbooks differ relates to the human cost of Stalin's rule. Book A1 (1974) condemns Stalin's cruelty and the great cost of human life during the purges but skims over the loss of life during industrialisation. Books A2 (1987) and A3 (1989), in contrast, see the modernisation of Russia as necessary and therefore the human cost as necessary collateral damage. As a result both textbooks focussed more on the economic and industrial successes of Russia under Stalin than on the cost to human life. In comparison to Lenin and Stalin, Trotsky is backgrounded. However, his consistent presence in all three Apartheid era History textbooks signifies his importance in the establishment of Communist Russia. 
As mentioned above, there is a discernible anti-Tsar sentiment running through all three the Apartheid era History textbooks serving a Republican orientated NP regime. Tsar Nicholas II is represented in all three textbooks as oppressive and being indifferent to the needs of the Russian people. At the same time he is accused of contributing to Russia remaining a backward country. Additionally, he is considered weak and ill-equipped to deal with Russia’s problems and is blamed for, not only the fall of Tsarist Russia, but the rise of Communist Russia.

Book A3 (1989) were especially vitriol in its representation of the Tsar and presented Communism as being a respite from his oppressive rule. In so doing Book A3 (1989) adopted a less critical approach to Communism when compared to Books A1 (1974) and A2 (1987). South Africa had outlawed Communism in 1950, and the ideology of the ruling NP was diametrically opposed to it. Consequently, both textbooks A1 (1974) and A2 (1987) highlighted the dangers of a revolutionary party by adopting an anti-revolutionary stance. In so doing the books offered a veiled warning against extra parliamentary groups. This was done by highlighting how a revolutionary party, such as the Bolsheviks, can ruin a country. In contrast, Book A3 (1989), by dint of the fact that it was published when radically political changes were facing South African and Russia, adopted a less critical approach to Communism. However, what all three textbooks did was to rile against Communism while, since it was illegal to do so, failing to provide a description of what Communism actually entails. As a result neither History teachers nor learners were offered a balanced understanding as to what Communism entailed.

In conclusion, the Apartheid era History textbooks outlined the same turn of events that created a Communist Russia and foregrounded the same male historical characters. Apart from minor differences the representation of Russian History within all three Apartheid textbooks remained largely similar.

\section{Analysis - Findings on the representation of Russia in the content of post- Apartheid era History textbooks}

The sampled post-Apartheid History Textbooks were written for the CAPSHistory curriculum currently in use. Contextually the post-Apartheid textbooks were published in a South Africa where Communism was no longer banned but closely intertwined with the ruling ANC government. The historical periods selected, Russia under the Tsarist Regime, Russia during the 
Bolshevik Revolution, Russia under Lenin and Russia under Stalin mirrored those of the Apartheid era. This in itself demonstrates continuity in terms of historical content.

The three post-Apartheid era History textbooks, B1 (2012), B2 (2012) and B3 (2012) displayed a clear anti-Tsarist sentiment. As with the Apartheid era textbooks Tsar Nicholas II was represented as weak, oppressive, backward and perpetuating an oppressive and unsuccessful reign.

In the post-Apartheid era History textbooks big male characters, Tsar Nicholas II, Vladimir Lenin, Leon Trotsky and Joseph Stalin, similar to those found in the Apartheid era textbooks, dominated the historical content. However, a significant change is the portrayal of Trotsky in much more detailed than under Apartheid. However, the main focus was still on Lenin and Stalin. In textbooks B1 (2012) and B 2 (2012) Lenin emerges as a hero and an admirable leader. Especially Book B2 (2012) offered a balanced portrayal of Lenin and called into question his actions and debated his hero legacy. In contrast, Stalin and his legacy were debated and questioned by all three postApartheid era textbooks. In the process he was presented as either a hero or a tyrant. For example, Book B1 (2012), denied Stalin a hero status because of the human cost to his rule which was deemed unjustifiable. In contrast, Book B3 (2012) perceived the human cost under Stalin to be worthwhile since it resulted in a modern Russia. However, the most radical departure by the three post-Apartheid from the past is sections on the role of women during the Russian Revolution. This constituted a mighty blow to the male hegemony the Apartheid era textbooks tended to attributed to the Russian Revolution.

In line with the changes that took place in post-Apartheid South Africa all three textbooks analysed offered a basic description of the origins of Communism and what the ideology entailed. This is a radical departure from the Apartheid era and is indicative of how much South Africa and History at school, has changed since 1994. At the same time none of the post-Apartheid era History textbooks displayed an anti-Communist outlook. Instead, Books B1 (2012) and B2 (2012) offered a somewhat positive representation of the Bolsheviks as a revolutionary party. This did not prevent Book B2 (2012) from also offering a critical perspective on Bolshevism and totalitarian rule.

Despite the afore-mentioned, all three textbooks (B1, B2, B3) still adopted a pro-Western lens to understand Russia. For example, although Russia was represented as having modernised, this was linked to aid offered by the West as well as the need for forms of Capitalism within Russia's economy. 
Although the three post-Apartheid History textbooks offered content to that found in the Apartheid era textbooks, in other ways the content had radically changed. This includes the adoption of a more critical approach, the appearance of women as leading historical characters and the normalisation of Communism as an ideology. As such the representation of Russia in postApartheid History textbooks exhibits both sweeping changes and moments of continuity.

\section{Discussion}

To society at large, and many a time to teachers and learners as well, historical content or substantive knowledge is what constitutes History at school. Although this is a dated idea it powerfully maintains currency. Looking at the historical content used to represent Russia in South African History textbooks across the Apartheid and post-Apartheid eras was, therefore, an exercise in trying to understand what has changed and what has remained the same. This was done against a backdrop of radical political changes in South African which also ushered in fundamental changes to the teaching and learning of History at school level.

What then has changed and what has continued in terms of the representation of Russia in South African History textbooks across the Apartheid and postApartheid eras? First and foremost the historical periods studied, the Tsarist Regime, Russia during the Bolshevik Revolution, Russia under Lenin and Russia under Stalin, remained remarkably similar across the two political eras. Consequently, the general historical events and characters also maintained a certain similarity. The rationale for this is relatively simple - the eras as outlined and the historical characters as identified are the benchmarked historical content on modern Russia. Reason being that these was the events and characters that birthed an alternative ideology and economic and political order, the like of which the world has never experienced before. How it unfolded and why it happened in Russia is therefore standard historical fare. The result was a certain transferability of historical content between curricula and educational material of the two very different political eras. Such a transfer is not necessary a strange practice especially since textbook producers are generally under pressure to present a commercial product to a government textbook vetting committee and the market. Additionally, most textbooks authors are not experts on Russian History and are relying on academic History publications which are recontextualised as school History. 
Many a time the available historical publications will also have a certain proWestern bias. Inevitably, considering the aforementioned, a certain similarity in terms of textbook content are to be found between the Apartheid and postApartheid publications.

However, if would be fair to say that Russia was not portrayed uniformly across the Apartheid and post-Apartheid era History textbooks. Internationally the limited literature we came across about Russia in History textbooks presented the country uniformly as backward and ruled by tyrannical rulers (Anderson, 1954; Burkhardt, 1947-1948; Paddock, 1998). However, apart from Russia under Tsar Nichols II, both the Apartheid and post-Apartheid era textbooks did not necessarily view Russia as backwards. Especially the large scale modernisation and industrialisation processes that took place under Communism were presented in a relatively positive light. And although Tsar Nicholas II and Stalin were seen as tyrants, Lenin was presented in the textbooks of both the Apartheid and post-Apartheid eras as anything but that. A telling departure from the international literature and the Apartheid era textbooks is the critical engagement with both Lenin and Stalin by the post-Apartheid era books (B1, B2 and B3). At the same time women as historical characters who played an important role in the Russian Revolution were foregrounded. This constituted a radical departure from the male hegemonic Russian History found in the Apartheid era textbooks and the international literature.

The most telling change in the representation of Russia in the Apartheid and post-Apartheid era History textbooks is the engagement with Communism as an ideology. In the Apartheid era textbooks, in line with the political ideology of the NP and within the context of the Cold War, Russia and Communism was the "Red Peril". Communism was foregrounded as a threat to especially Capitalism and the white way of life. Such was the fear of this peril that it was illegal to explain the nature of Communism or say anything positive about it. This ideological position permeated the representation of Russia in the Apartheid era textbooks. In contract, post-1994, Communism and Russia has both been liberated and normalised. Not only is the SACP part of the ruling government but Communism, and what it entails as an ideology is unpacked, be it at a rudimentary level, in the History textbooks. At the same time Russia is no longer a place to be feared because of an ideology it once embraced, but rather a place inhabited by people who faced their own challenges in the past.

The above-mentioned is the most deep-seated change in content on Russia between the Apartheid and post-Apartheid era History textbooks. Since 
History textbooks are both educational and political constructions it carries selected narratives linked to a desired ideology with the aim to instil a common set of values and identities (Engelbrecht, 2006; Foster, 2011). This was, with reference to Russia done under Apartheid and is also happening in a post-Apartheid context. Consequently Russia was, and still is, a refashioned historical memory gleaned from desired historical conceptions (Porat, 2004; Stojanovic, 2001; Zajda, 2007) as History at school level moulded itself to the political order of the day (Apple, 2004; Apple \& Christian-Smith, 1991). In all of this History textbooks were employed, with reference to Russia, during both political eras, as constructors and disseminators of national narratives and identities.

With reference to the above, school History under Apartheid was a memory discipline underpinned by a white supremacy ideology and based on a master narrative that was not to be contested. As an ideology if was forcefully dispensed and resulted in a very specific identity and consciousness - both in general terms and how it related to Russia. In contrast, in the post-Apartheid context, school History is seen as a disciplinary discipline that welcomes critical engagement and different perspectives. This is part of what it means to be living in a constitutional democracy and means that Russia, as represented in History textbooks, as well as the ideology and identity politics at play, can be challenged and contested. This is singularly the most important differences between engaging with the content on Russia in History textbooks in the Apartheid and post-Apartheid eras.

\section{Conclusion}

This article, comparative by nature, allowed for a reflection on change and continuity and similarities and differences (Cavalli, 2016; Nishino, 2006) as it related to the representation of Russia in History textbooks of the Apartheid and post-Apartheid eras. What emerged is, that while the overarching structure of the representation of Russian History generally remained uniform across the two eras certain discernible did exits on how Russia were viewed. In the context of the Apartheid era History textbooks Russia was, for the most part, a country equated to Communism and all the negativity the Apartheid state associated with this ideology. It was also a place where tough men generally ruled in either an incompetent or tyrannically manner. However, between 1974 and 1989, the timeframe the analysed Apartheid era textbooks spans, a more empathetic tone started towards Russia started to emerge. This in 
itself was a reflection of the political changes that were taking place in South Africa and which started to pave the way for a different narrative on national identity.

The post-Apartheid era History textbooks, while covering the same historical eras and similar content to their Apartheid era counterparts, were clearly a product of the new South Africa and all it entailed. Russia and Communism were no longer the "Red Scare" but a country whose History was engaged with critically. In the process different perspectives were expressed about the Russian leaders studied and women appeared as historical characters in their own right. Overall, school History, as it related to Russia were starting to reflect the social realities of the post-Apartheid political and educational order with new national narratives and identities being promoted by the History textbooks studied.

\section{References}

Anderson, MS 1954. English views of Russia in the 17th ventury. The Slavonic and East European Review, 33(80):140-160.

Apple, MW 2004. Ideology and curriculum. New York: Routledge.

Apple, MW \& Christian-Smith, LK 1991. The politics of the textbook. In: MW Apple \& LK Christian-Smith (eds.). The politics of the textbook. New York: Routledge.

Bauer, M, Gaskell, G \& Allum, N 2000. Quality, quantity and knowledge interests: Avoiding confusions. In: M Bauer \& G Gaskell (eds.). Qualitative researching with text, image and sound. A practical handbook. New York: Sage.

Bertram, C \& Wassermann, JM 2015. South African history textbook research - A review of the scholarly literature. Yesterday\&Today, 14, Dec 2015:151-174.

Bertram, C \& Bharath, P 2011. Specialised knowledge and everyday knowledge in old and new Grade 6 history textbooks. Education as Change, 15(1):63-80.

Burkhardt, R 1947-1948. The Soviet Union in American school textbooks. The Public Opinion Quarterly, 11(4):567-571.

Cavalli, A 2016. The comparative approach and its educational value. International Journal for History and Social Sciences Education, 2016(1):20-30.

Chisholm, L 2015. Curriculum in transition in Germany and South Africa: 1990-2010. Comparative Education, 51(3):401-418.

Cohen, L \& Manion, L 1994. Research methods in education. New York: Routledge. 
Da Cruz, P 2005. From narrative to severed heads. The form and location of white supremacist history in textbooks of the Apartheid and post-Apartheid eras. A case study. MEd dissertation. Cape Town: University of Cape Town.

Denzin, N \& Lincoln, Y 2008. Introduction. In: N Denzin \& Y Lincoln (eds.). Strategies of qualitative inquiry. New York: Sage.

Du Preez, JM 1983. African Afrikaner. Master symbols in South African school textbooks. Alberton: Librarius Felicitas.

Elo, S \& Knygäs, H 2008. The qualitative content analysis process. Journal of Advanced Nursing, 62(1):107-115.

Engelbrecht, A 2006. Textbooks in South Africa from Apartheid to post-Apartheid: Ideological change revealed by racial stereotyping. In: E Roberts-Schweitzer, V Greaney \& K Duer (eds.). Promoting social cohesion through education. Case studies and tools for using textbooks and curricula. Washington: World Bank.

Foster, S 2011. Dominant traditions in international textbook research and revision. Education Inquiry, 2(1):5-20.

Foster, S \& Crawford, K 2006. The critical importance of History textbook research. In: S Foster \& K Crawford (eds.). What shall we tell the children? International perspectives on school History textbooks. Greenwich: Information Age Publishing.

Hsieh, HF \& Shannon, SE 2005. Three approaches to qualitative content analysis. Qualitative Health Research, 15(9):1277-1288.

Kahlke, R 2014. Generic qualitative qpproaches: Pitfalls and benefits of methodological mixology. International Journal of Qualitative Methods, 2014:37-52.

Nishino, R 2006. A comparative historical study of Japanese and South African history textbooks ca. 1945-1995. Phd-thesis. Perth: University of Western Australia.

Paddock, T 1998. Plenty of barbarians and no bird's milk: The depiction of Russia in German school books 1890-1914. Internationale Schulbuchforschung, 20(1):35-50.

Paxton, R 1999. A deafening silence: History textbooks and the students who read them. Review of Educational Research, 69(3):315-339.

Pingel, F 2010. UNESCO Guidebook on textbook research and textbook revision, 2. Paris: UNESCO.

Porat, D 2004. It's not written here, but this Is what happened: Students' cultural comprehension of textbook narratives on the Israeli-Arab conflict. American Educational Research Journal, 41(4):963-996.

Pratte, R 1977. Ideology and education. New York: David McKay.

Stojanovic, D 2001. History textbooks and creation of national identity. Teaching the History of Southeastern Europe. Thessaloniki: Petros Th. Ballidis.

Teddlie, C \& Yu F 2007. Mixed methods sampling: A typology with examples. Journal of Mixed Methods Research, 1(1):77-100. 
Wang, Z 2009. Old wounds, new narratives: Joint History textbook writing and peacebuilding in East Asia. History and Memory, 21(1):101-126.

Wassermann, JM 2018. The state and the volving of teaching about apartheid in school history in South Africa, circa 1994-2016. In: T Epstein \& C Peck (eds.). Teaching and learning difficult histories in international contexts-a critical approach. New York: Routledge.

Zajda, J 2007. The new History school textbooks in the Russian Federation: 1992-2004. Compare: A Journal of Comparative Education, 37(3):291-306.

Zajda, J \& Zajda, R 2003. The politics of rewriting History: New History textbooks and curriculum materials in Russia. International Review of Education, 49(3/4):363-384.

Zhao, S 2001. Metatheorizing in Sociology. In: G Ritzer \& B Smart (eds.). Handbook of social theory. New York: Sage. 